\title{
Biological activity of 3-(2-benzoxazol-5-yl)alanine derivatives
}

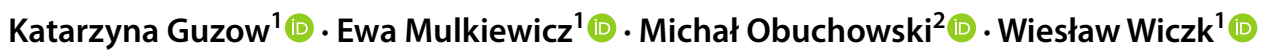

Received: 16 February 2021 / Accepted: 25 June 2021 / Published online: 8 July 2021

(c) The Author(s) 2021

\begin{abstract}
Searching for new drugs is still a challenge for science, mainly because of civilization development and globalization which promote the rapid spread of diseases, which is particularly dangerous in the case of infectious ones. Moreover, readily available already known antibiotics are often overused or misused, possibly contributing to the increase in the number of multidrug-resistant microorganisms. A consequence of this is the need for new structures of potential drugs. One of them is a benzoxazole moiety, a basic skeleton of a group of fluorescent heterocyclic compounds already widely used in chemistry, industry, and medicine, which is also present in naturally occurring biologically active compounds. Moreover, synthetic benzoxazoles are also biologically active. Considering all of that, a large group of non-proteinogenic amino acids based on 3-(2-benzoxazol-5-yl)alanine skeleton was studied in search for new antimicrobial and anticancer agents. Screening tests revealed that antibacterial potential of 41 compounds studied is not very high; however, they are selective acting only against Gram-positive bacteria (B. subtilis). Moreover, almost half of the studied compounds have antifungal properties, also against pathogens (C. albicans). Most of studied compounds are toxic to both normal and cancer cells. However, in a few cases, toxicity to normal cells is much lower than for cancer cells indicating these compounds as future anticancer agents. The research carried out on such a large group of compounds allowed to establish a structure-activity relationship which enables to select candidates for further modifications, necessary to improve their biological activity and obtain a new lead structure with potential for therapeutic use.
\end{abstract}

Keywords Benzoxazole $\cdot$ Amino acid $\cdot$ Antibiotic $\cdot$ Antifungal agent $\cdot$ Cytotoxicity

\section{Introduction}

Civilization development and globalization significantly contribute to the rapid spread of diseases, especially infectious ones. Moreover, the readily available already known antibiotics are often overused or misused, resulting in an increase in the number of multidrug-resistant microorganisms. Therefore, the search for new effective drugs is still an important challenge for scientists.

Among new structures of potential drugs, a benzoxazole moiety is interesting and promising one. This heterocyclic

Handling editor: T. Langer.

Katarzyna Guzow

katarzyna.guzow@ug.edu.pl

1 Faculty of Chemistry, University of Gdańsk, Wita Stwosza 63, Gdańsk 80-308, Poland

2 Laboratory of Molecular Bacteriology, Intercollegiate Faculty of Biotechnology, Medical University of Gdańsk, Dębinki 1, Gdańsk 80-211, Poland compound is a structural motif present in naturally occurring biologically active compounds isolated from marine sponges (Daletos et al. 2014; Pal et al. 2018; Takahashi et al. 2011) or gorgonian corals (Pal et al. 2018) as well as from bacteria (mainly Actinomycetes and Streptomyces species (Fig. 1a) Chu et al. 2011; Hohmann et al. 2009; Pal et al. 2018; Sommer et al. 2008; Sun et al. 2015). Also, metabolites of some Streptomyces sp. (Sato et al. 2001; Ueki et al. 1993, 1997; Ueki and Taniguchi 1997) and antibiotics of calcimycin class (Prudhomme et al. 1984, 1986a, b; Sarma et al. 2003) contain benzoxazole ring. These compounds as well as their derivatives and analogues have mainly antibacterial, antifungal, antituberculotic, and/or anticancer activity (Pal et al. 2018; Prudhomme et al. 1984, 1986a, b; Reynolds et al. 1999; Sato et al. 2001; Sarma et al. 2003; Ueki et al. 1993, 1997; Ueki and Taniguchi 1997). Based on that, benzoxazole ring becomes a main skeleton of many synthetic derivatives (Fig. 1b) including some antibacterial and antifungal agents, in some cases even more active than widely used antibiotics (Arpaci et al. 2002a, b; de Carvalho et al. 2017; Jauhari et al. 
(a)

Actinomycetes sp.<smiles>[R]Cc1ncc([R20])c(-c2nc3c(C(=O)N[R])c([R])cc(C)c3o2)n1</smiles>

$$
\begin{array}{lll}
\text { Boxazomycin A } & \mathrm{R}^{1}=\mathrm{R}^{4}=-\mathrm{OH} & \mathrm{R}^{2}=\mathrm{R}^{3}=-\mathrm{H} \\
\text { Boxazomycin B } & \mathrm{R}^{1}=-\mathrm{OH} & \mathrm{R}^{2}=\mathrm{R}^{3}=\mathrm{R}^{4}=-\mathrm{H}
\end{array}
$$<smiles>COc1cc(O)ccc1-c1nc2cc(CO)ccc2o1</smiles>

Nocarbenzoxazole G
Streptomyces sp.<smiles>[R]c1cccc(O)c1-c1nc2c(-c3nc4c(C(=O)OC)cccc4o3)cccc2o1</smiles>

UK-1 $\quad \mathrm{R}=-\mathrm{H}$

Nataxazole $\mathrm{R}=-\mathrm{CH}_{3}$<smiles>O=C(O)c1cccc2oc(-c3ccccc3O)nc12</smiles>

Caboxamycin

(b)<smiles>O=C(Cc1ccccc1)Nc1ccc2oc(-c3ccc(F)cc3)nc2c1</smiles><smiles>[R]c1ccc([N+](=O)[O-])c(-c2nc3cc(C(=O)O)ccc3o2)c1</smiles>

$$
\mathbf{R}=-\mathbf{H} \text { or }-\mathbf{F}
$$<smiles>OCc1ccc2oc(-c3ccc(O)cc3O)nc2c1</smiles><smiles>Nc1ccc(-c2nc3ccccc3o2)cc1</smiles><smiles>Brc1ccc2oc(-c3cnc4ccccc4n3)nc2c1</smiles>

(c)<smiles>CCCCOC(=O)OCCCCC(C)c1ccc2oc(-c3ccc(Cl)cc3)nc2c1</smiles><smiles>C[C@@H](C(=O)O)c1ccc2oc(-c3ccc(F)cc3)nc2c1</smiles>

Flunoxaprofen

Fig. 1 Structures of selected biologically active compounds containing benzoxazole moiety: a natural; b synthetic; $\mathbf{c}$ non-steroidal anti-inflammatory drugs 
2008; Kakkar et al. 2018; Kakkar and Narasimhan 2019; Kuroyanagi et al. 2010, 2011; Rida et al. 2005; Sattar et al. 2020; Şener et al. 2000; Tekiner-Gulbas et al. 2007; Temiz et al. 1998, 2008; Zhang et al. 2018). It was observed that some compounds based on benzoxazole have antituberculotic (Ertan-Bolelli et al. 2016; Pytela and Klimešová 2011; Rana et al. 2014a, b; Šlachtová and Brulíková 2018; Zhang et al. 2018), or antimalarial (Ongarora et al. 2015; Zhang et al. 2018), or antiviral activity (Bernard et al. 2014; Demmer and Bunch 2015; Jonckers et al. 2012; Sattar et al. 2020; Zhang et al. 2018). Moreover, it was demonstrated that a large group of benzoxazole derivatives exert cytotoxic effect on some cancer cells such as breast cancer cells (MCF-7, MDA-MB-213, MDA-MB-231), lung cancer cells (A549, H1975, HCC827), liver cancer cells (HepG2), prostate cancer cells (PC3), colorectal cancer cells (HCT-116, HT-29), oral cancer cells (KB), melanoma cells (A375), and others (Bernard et al. 2014; Chung et al. 2015; Desai et al. 2020; Giordano et al. 2019; Han et al. 2012; Kakkar et al. 2018; Kakkar and Narasimhan 2019; Kumar et al. 2002; Li et al. 2015; Omar et al. 2020; Reddy et al. 2016; Reynolds et al. 1999; Rida et al. 2005; Sachweh et al. 2015; Sato et al. 2001; Sattar et al. 2020; Sever et al. 2021; Slotkin et al. 2016; Ueki et al. 1993, 1997; Zhang et al. 2018; Zhong et al. 2020; Zi et al. 2019).

Among benzoxazole derivatives, there are potential anticonvulsant (Ibrahim et al. 2015; Sattar et al. 2020; Song et al. 2019; Zhang et al. 2018) or antipsychotic agents (Huang et al. 2015). They are also known as muscle-relaxant, sedative, diastolic, or anti-inflammatory agents (Dunwell et al. 1975a, b; Kaur et al. 2018; Sattar et al. 2020; Seth et al. 2014; Zhang et al. 2018). Moreover, benzoxazole moiety was a core pharmacophoric unit of commercially available non-steroidal anti-inflammatory drugs - benoxaprofen and flunoxaprofen (Fig. 1c, Dunwell et al. 1975a, b). However, because of the observed side effects of benoxaprofen (Lewis et al. 1990), both pharmaceuticals were withdrawn from the market. Nowadays, this heterocyclic ring is present in compounds tested as potential drugs for neurodegenerative diseases such as Alzheimer's (Gutti et al. 2019; Zhang et al. 2018) or prion diseases (Hyeon et al. 2020).

Synthetic benzoxazole derivatives have often wide spectrum of antimicrobial activity. A large group of benzoxazole derivatives show antibacterial activity against Grampositive bacteria (Staphylococcus aureus, Streptococcus faecalis, Bacillus subtilis) and/or Gram-negative bacteria (Escherichia coli, Klebsiella pneumoniae, Pseudomonas aeruginosa), and/or antifungal activity (Candida albicans, Candida krusei, Candida glabrata, Candida-6, Candida-51, Aspergillus niger, Aspergillus flavus), which in some cases is higher than the activity of the commercially available antimicrobial drugs used as controls. In many cases, a structure-activity relationship is observed and it was found that the most important are substituents in positions 2 and 5 of the benzoxazole ring, especially if both of them are occupied (Arpaci et al. 2002a; Demmer and Bunch 2015; Kuroyanagi et al. 2011; Sattar et al. 2020; Tekiner-Gulbas et al. 2007).

Taking these facts into account, we decided to study biological activity of a large group of non-proteinogenic amino acid derivatives based on benzoxazole skeleton. All 41 derivatives of 3-(2-benzoxazol-5-yl)alanine contain in position 5 of the benzoxazole amino acid moiety, whereas in position 2, various substituents such as phenyl, hydrocarbon, or heterocyclic group (Fig. 2).

\section{Materials and methods}

\section{Synthesis}

All studied compounds (Fig. 2) were obtained previously (Guzow et al. 2001, 2002, 2003, 2004, 2005a, b, 2007, 2012). To improve their solubility in water, the protecting groups were removed. For all compounds, the protection of $\alpha$-amino group (Boc) was removed selectively by acidic hydrolysis using trifluoroacetic acid in dichloromethane $(50: 50(\mathrm{v} / \mathrm{v}))$ (Guzow et al. 2003, 2012). Additionally, in a few cases (compounds 36-41, Fig. 2), first, the protection of $\alpha$-carboxyl group (methyl ester) was removed using basic hydrolysis (1 M NaOH in methanol) (Guzow et al. 2003). The purity of the obtained compounds was at least $96 \%$. It was checked by means of RP-HPLC (Varian) with UV detection $(223 \mathrm{~nm})$ using analytical Kromasil column (C-8, $5 \mu \mathrm{m}, 250 \mathrm{~mm}$ long, i.d. $=4.5 \mathrm{~mm}$ ). The mobile phase was a gradient running from $0.1 \%$ water solution of trifluoroacetic acid (phase A) to $80 \%$ of acetonitrile in phase A (phase B) over $60 \mathrm{~min}$. The identification of all products was based on mass spectra recorded on Bruker Biflex III (MALDI-TOF) or MASSLAB TRIO-3 (FAB) instrument. In each case, $(\mathrm{M}+\mathrm{H})^{+}$or $\mathrm{M}^{+}$ion was detected.

\section{Microbiological studies}

Antibacterial and antifungal assays were performed in vitro. First, the screening tests using Bacillus subtilis ATCC 23857 and Escherichia coli ATCC 25922 as model Gram-positive and Gram-negative bacteria, respectively, and yeast Pichia pastoris as model fungus were performed for all compounds. Such strains were chosen as representatives of the two largest groups of bacteria (B. subtilis and E. coli) and primitive Eucaryota ( $P$. pastoris). Then, the active compounds were selected and tested against most common pathogens such as Staphylococcus aureus ATCC 25923, Enterococcus faecalis ATCC 29212, Pseudomonas aeruginosa ATCC 27853, and Candida albicans ATCC 10231. 
<smiles>[Y]c1c([Y4])c([Y4])c(-c2nc3cc(C[C@H](N)C(=O)OC)ccc3o2)c([Y8])c1[Y4]</smiles>

$\mathrm{H}-\mathrm{Box}\left[\left(\mathrm{Y}_{\mathrm{x}}\right) \mathrm{Ph}\right]-\mathrm{OMe}$

\begin{tabular}{|c|c|c|c|c|}
\hline & $Y_{1}$ & $\mathrm{Y}_{2}$ & $\mathbf{Y}_{3}$ & $\mathrm{Y}_{4}$ \\
\hline 1: & $\mathrm{H}$ & $\mathrm{H}$ & $\mathrm{CH}_{3}$ & $\mathrm{H}$ \\
\hline 2: & $\mathrm{H}$ & $\mathrm{H}$ & $\mathrm{F}$ & $\mathrm{H}$ \\
\hline 3: & $\mathrm{H}$ & $\mathrm{H}$ & $\mathrm{CN}$ & $\mathrm{H}$ \\
\hline 4: & $\mathrm{H}$ & $\mathrm{H}$ & $\mathrm{COOH}$ & $\mathrm{H}$ \\
\hline 5: & $\mathrm{H}$ & $\mathrm{H}$ & $\mathrm{Br}$ & $\mathrm{H}$ \\
\hline 6: & $\mathrm{OCH}_{3}$ & $\mathrm{H}$ & $\mathrm{H}$ & $\mathrm{H}$ \\
\hline $7:$ & $\mathrm{OCH}_{3}$ & $\mathrm{H}$ & $\mathrm{H}$ & $\mathrm{OCH}_{3}$ \\
\hline 8: & $\mathrm{OCH}_{3}$ & $\mathrm{H}$ & $\mathrm{OCH}_{3}$ & $\mathrm{OCH}_{3}$ \\
\hline 9: & $\mathrm{H}$ & $\mathrm{OCH}_{3}$ & $\mathrm{OCH}_{3}$ & $\mathrm{OCH}_{3}$ \\
\hline $10:$ & $\mathrm{H}$ & $\mathrm{H}$ & $\mathrm{OCH}_{2} \mathrm{CHCH}_{2}$ & $\mathrm{H}$ \\
\hline 11: & $\mathrm{H}$ & $\mathrm{H}$ & $\mathrm{NMe}_{2}$ & $\mathrm{H}$ \\
\hline $12:$ & $\mathrm{H}$ & $\mathrm{H}$ & $\mathrm{NPh}_{2}$ & $\mathrm{H}$ \\
\hline 13: & $\mathrm{OCH}_{3}$ & $\mathrm{H}$ & $\mathrm{NMe}_{2}$ & $\mathrm{H}$ \\
\hline 14: & $\mathrm{OH}$ & $\mathrm{H}$ & $\mathrm{NEt}_{2}$ & $\mathrm{H}$ \\
\hline $15:$ & $\mathrm{OH}$ & $\mathrm{H}$ & $\mathrm{OH}$ & $\mathrm{H}$ \\
\hline $16:$ & $\mathrm{H}$ & $\mathrm{H}$ & $\mathrm{B}(\mathrm{OH})_{2}$ & $\mathrm{H}$ \\
\hline $17:$ & $\mathrm{H}$ & $\mathrm{B}(\mathrm{OH})_{2}$ & $\mathrm{H}$ & $\mathrm{H}$ \\
\hline 18: & $\mathrm{H}$ & $\mathrm{OPh}$ & $\mathrm{H}$ & $\mathrm{H}$ \\
\hline $19:$ & $\mathrm{H}$ & $\mathrm{CF}_{3}$ & $\mathrm{H}$ & $\mathrm{CF}_{3}$ \\
\hline
\end{tabular}<smiles>[Y]c1nc2cc(C[C@H](N)C(=O)OC)ccc2o1</smiles>

H-Box(Y)-OMe<smiles>[Y]C=Cc1ccc(N(C)C)cc1</smiles>

20<smiles>Cc1ccc(C)s1</smiles>

22

23<smiles>Cc1sc2ccccc2c1C</smiles>

25<smiles>Cc1ccc2ccccc2n1</smiles>

28<smiles>Cc1ccncc1</smiles>

26<smiles>Cc1cnc2ccccc2c1</smiles>

29<smiles>Cc1ccc2ncccc2c1</smiles>

31<smiles>[Y]c1nc2cc(C[C@H](N)C(=O)OC)cc(Br)c2o1</smiles>

$\mathrm{H}-\mathrm{Box}(\mathrm{YBr})-\mathrm{OMe}$<smiles>CCc1ccc(C)o1</smiles>

21<smiles>Cc1c[nH]c2ccccc12</smiles>

24<smiles>Cc1ccccn1</smiles>

27<smiles>Cc1cc2ccccc2cn1</smiles>

30<smiles>Cc1cccc2cccnc12</smiles>

33<smiles>[Y]c1nc2cc(C[C@H](N)C(=O)O)ccc2o1</smiles>

$\mathbf{Y}=$<smiles>Cc1ccc(C)cc1</smiles>

36<smiles>Cc1ccc(-c2ccccc2)cc1</smiles><smiles>Cc1ccc2ccccc2c1</smiles><smiles>Cc1c2ccccc2cc2ccccc12</smiles>

39

$\mathbf{Y}=$<smiles>Cc1ccncc1</smiles>

38

37

Fig. 2 Structures of studied compounds 
Bacterial strains were subcultured overnight prior to the assay in Mueller-Hinton broth (Difco) at $37{ }^{\circ} \mathrm{C}$. Pichia pastoris and Candida albicans were subcultured overnight at $25^{\circ} \mathrm{C}$ in Mueller-Hinton and Luria-Bertani (Difco) broth, respectively, supplemented with $2 \%$ of glucose.

Screening tests against model microorganisms as well as against pathogens were carried out on the appropriate broth solidified by agar using antibiogram method and twofold serial dilution technique (Wiegand et al. 2008). Water solution of each studied compound ( $5 \mu \mathrm{l})$ was deposited on absorbent paper disk (Whatman 3MM) which was placed on Petri dish with medium inoculated with appropriate microorganism $(50 \mu \mathrm{l}$ of inoculum prepared by diluting the subcultured microorganism in its incubation broth to optical density at $570 \mathrm{~nm}\left(\mathrm{OD}_{570}\right)$ equal to 1$)$. Each dish contains six paper disks - maximal concentration of the compound and its five serial dilutions. After the incubation for $24 \mathrm{~h}$ at $37{ }^{\circ} \mathrm{C}$ (bacteria) or $48 \mathrm{~h}$ at $25{ }^{\circ} \mathrm{C}$ (fungi), diameters of growth inhibition zones were measured.

The active compounds were selected and their minimal inhibitory concentration (MIC) values were determined in 96-well flat-bottomed microtiter plates using twofold serial dilution technique. Each compound was dissolved in appropriate broth, then serially diluted and $50 \mu \mathrm{l}$ of each solution was transferred in duplicate to the wells. The microbial inoculum $\left(\mathrm{OD}_{570} \approx 0.01\right)$ was added to the samples to achieve a final volume of $100 \mu$ l. Every test plate contains growth (inoculated broth) and blank (only studied compound in broth) controls. After $24 \mathrm{~h}$ incubation at $37{ }^{\circ} \mathrm{C}$ (bacteria) or $25^{\circ} \mathrm{C}$ (fungi), optical density was measured at $570 \mathrm{~nm}$ using Elx800 Absorbance Reader (Bio-Tek Instruments). The lowest concentration of studied compound that completely inhibited growth of microorganism in well was taken as MIC value.

\section{Cytotoxicological studies}

Cytotoxicity was determined using four different mammalian cell lines: rat glioma (C6), mouse fibroblasts (A9), human embryonic kidney (Hek293), and human dermal fibroblasts (HDF). The cells were grown as a monolayer in low-glucose (HDF) or high-glucose (C6, A9, Hek293) DMEM medium supplemented with $1 \%$ antibiotic solution (penicillin/streptomycin), $1 \%$ glutamine, and $10 \%$ fetal bovine serum (FBS) at $37{ }^{\circ} \mathrm{C}$ in a humidified atmosphere of $5 \% \mathrm{CO}_{2}$. All culture media and supplements were obtained from Gibco. The medium was changed every 2 days and cells were subcultured. For the cytotoxicity assays, cells were seeded in 96-well plates at an initial density of $2.5 \times 10^{4}(\mathrm{C} 6, \mathrm{~A} 9)$ or $4 \times 10^{4}$ (HDF, Hek293) cells per $\mathrm{ml}$ of appropriate culture medium and incubated for $24 \mathrm{~h}$.

A colorimetric assay with WST-1 reagent (2-(4-iodophenyl)-3-(4-nitrophenyl)-5-(2,4-disulfophenyl)-
2H-tetrazolium monosodium salt, Roche Diagnostics) was used for the cell viability tests. Stock solutions of the tested compounds were prepared in growth media with $0.5 \%$ DMSO added to improve solubility. Cells were exposed to nine different concentrations (from $2 \mu \mathrm{M}$ to $10 \mathrm{mM}$ ) of the tested compounds. Each incubation, including blank and growth controls, was performed in triplicate. The cells were incubated for $44 \mathrm{~h}$. After this time, $10 \mu \mathrm{l}$ of WST-1 reagent, was added to each well and incubated for $4 \mathrm{~h}$ at $37^{\circ} \mathrm{C}$. Subsequently, the absorbance at $450 \mathrm{~nm}$ was measured in the plate reader. Cell viability was calculated as the percentage of the viability of exposed cells vs. controls. These data are the means of three independent experiments conducted for each compound. Concentration response curves were fitted with the nonlinear least squares method using a logistic model for the relation of cell viability and inhibition to the decadic logarithm of the tested concentrations (Ranke et al. 2004). The $\log \mathrm{EC}_{50}$ values $\left(\mathrm{EC}_{50}\right.$ - half maximal effective concentration) were given, since it is a model parameter in the logistic model. Calculations were carried out with $\mathrm{R}$ language and environment for statistical computing (http:// www.r-project.org).

\section{Results and discussion}

\section{Antimicrobial activity}

Antimicrobial activity of all studied 3-(2-benzoxazol-5-yl) alanine derivatives was screened using model bacterial strains, Bacillus subtilis (Gram-positive) and Escherichia coli (Gram-negative), as well as yeast Pichia pastoris (representative of Eucaryota). It was found that only a few compounds were active. Minimal inhibitory concentrations (MIC) obtained for them are presented in Table 1.

Performed tests revealed that antibacterial potential of these compounds is rather low as only four derivatives were active (H-Box [2,4,5-(OMe) 3 Ph]-OMe (8), H-Box[(2-OMe4-NMe $\left.{ }_{2}\right) \mathrm{Ph}$-OMe (13), H-Box(2Q)-OMe (28), H-Box(8Q)$\mathrm{OMe}(\mathbf{3 3}))$ and their MIC values were very high (except for H-Box[(2-OMe-4-NMe 2 ) Ph]-OMe (13), Table 1). However, it was observed that they are selective being active only against $B$. subtilis (Gram-positive bacteria). The activity of these four compounds against pathogenic strains (S. aureus, E. faecalis, $P$. aeruginosa) was also studied, but the results were negative.

Antifungal properties of studied compounds were much more pronounced in comparison with antibacterial ones. Among 41 studied compounds, 16 showed activity against $P$. pastoris with MIC values much lower than these determined for $B$. subtilis (Table 1). Moreover, the structure-activity relationship was observed (Table 1). Among 20 derivatives with substituted phenyl in position 2 of the benzoxazole 
Table 1 Antimicrobial activity (MIC) of studied compounds against selected microorganisms

\begin{tabular}{|c|c|c|c|c|c|c|c|}
\hline \multicolumn{2}{|c|}{ Compound } & \multirow{2}{*}{\multicolumn{2}{|c|}{$\begin{array}{l}\text { Bacillus subtilis } \\
\text { MIC }\end{array}$}} & \multirow{2}{*}{\multicolumn{2}{|c|}{$\begin{array}{l}\text { Pichia pastoris } \\
\text { MIC }\end{array}$}} & \multirow{2}{*}{\multicolumn{2}{|c|}{$\begin{array}{l}\text { Candida albi- } \\
\text { cans }\end{array}$}} \\
\hline & & & & & & & \\
\hline No. & Designation & $(\mu \mathrm{g} / \mathrm{ml})$ & $(\mu \mathrm{M})$ & $(\mu \mathrm{g} / \mathrm{ml})$ & $(\mu \mathrm{M})$ & $(\mu \mathrm{g} / \mathrm{ml})$ & $(\mu \mathrm{M})$ \\
\hline 2 & H-Box[(4-F)Ph]-OMe & na & na & 63 & 200 & na & na \\
\hline 6 & H-Box[(2-OMe)Ph]-OMe & na & na & 146 & 448 & na & na \\
\hline 7 & $\mathrm{H}-\mathrm{Box}\left[2,5-(\mathrm{OMe})_{2} \mathrm{Ph}\right]-\mathrm{OMe}$ & na & na & 150 & 421 & na & na \\
\hline 8 & $\mathrm{H}-\mathrm{Box}\left[2,4,5-(\mathrm{OMe})_{3} \mathrm{Ph}\right]-\mathrm{OMe}$ & 6000 & 15544 & na & na & na & na \\
\hline 9 & $\mathrm{H}-\mathrm{Box}\left[3,4,5-(\mathrm{OMe})_{3} \mathrm{Ph}\right]-\mathrm{OMe}$ & na & na & 190 & 492 & na & na \\
\hline 13 & $\mathrm{H}-\mathrm{Box}\left[\left(2-\mathrm{OMe}-4-\mathrm{NMe}_{2}\right) \mathrm{Ph}\right]-\mathrm{OMe}$ & 190 & 515 & 46 & 125 & 196 & 531 \\
\hline 21 & H-Box(Fur)-OMe & na & na & 125 & 398 & na & na \\
\hline 23 & H-Box(Pyrrol)-OMe & na & na & 113 & 378 & na & na \\
\hline 26 & H-Box(4Py)-OMe & na & na & 160 & 539 & na & na \\
\hline 28 & H-Box(2Q)-OMe & 1100 & 3170 & 110 & 317 & 200 & 576 \\
\hline 29 & H-Box(3Q)-OMe & na & na & $2370^{*}$ & $6830^{*}$ & na & na \\
\hline 30 & H-Box(3iQ)-OMe & na & na & 140 & 403 & na & na \\
\hline 31 & H-Box(6Q)-OMe & na & na & $3950 *$ & $11383 *$ & na & na \\
\hline 32 & H-Box(4Q)-OMe & na & na & $1270^{*}$ & $3660^{*}$ & na & na \\
\hline 33 & H-Box(8Q)-OMe & 1050 & 3026 & 400 & 1153 & na & na \\
\hline 34 & H-Box(4PyBr)-OMe & na & na & 65 & 173 & 138 & 367 \\
\hline 35 & H-Box(2PyBr)-OMe & na & na & 352 & 936 & na & na \\
\hline
\end{tabular}

*Estimated value - concentration determined basing on tests on solidified broth because of too low solubility of the compound in the liquid broth (compounds 1-20, Fig. 2), only 5 were active (compounds $\mathbf{2}, \mathbf{6}, \mathbf{7}, \mathbf{9}, \mathbf{1 3}$, Fig. 2, Table 1). Four of these compounds $(6,7,9,13)$ have electron-donating substituents (methoxy, dimethylamino group), whereas only one (compound 2 ) has electron-accepting substituent (fluor). The most active compound was H-Box[(2-OMe-4-NMe $) \mathrm{Ph}]-\mathrm{OMe}(13)$ which also exhibited the highest antibacterial activity. Lack of dimethylamino group in position 4 of the phenyl ring of the tested compound, as in the case of $\mathrm{H}-\mathrm{Box}[(2-\mathrm{OMe}) \mathrm{Ph}]-\mathrm{OMe}$ (compound 6, Fig. 2), significantly decreases the activity of the compound (about threefold, Table 1). The presence of additional methoxy group in the phenyl ring (H-Box[2,5$\left.(\mathrm{OMe})_{2} \mathrm{Ph}\right]-\mathrm{OMe}$ (compound 7, Fig. 2)) does not affect much the antifungal activity of the compound as opposed to change in their positions, which has a greater effect (H-Box[3,4,5-(OMe) $\left.{ }_{3} \mathrm{Ph}\right]-\mathrm{OMe}$ (compound 9) - active, $\mathrm{H}-\mathrm{Box}\left[2,4,5-(\mathrm{OMe})_{3} \mathrm{Ph}\right]-\mathrm{OMe}$ (compound 8) - not active, Table 1). The slight decrease in MIC value (about 30\%) observed for compound 9 with 3 electron-donating methoxy groups may be due to the steric hindrance. Among compounds with hydrocarbon in position 2 of the benzoxazole ring (compounds 36-39, Fig. 2), no one was active which may be a result of steric hindrance of such substituent and/ or lack of methyl ester at the carboxyl group.

In the case of derivatives containing heterocyclic substituent in position 2 (compounds $\mathbf{2 1 - 3 5}$ and $\mathbf{4 0 - 4 1}$, Fig. 2), the activity was observed mainly for these with azaaromatic group (compounds 23-35, Table 1). The presence of a substituent with sulfur (compound 22, Fig. 2) or two heteroatoms (compound 40, Fig. 2) makes the compound inactive (Table 1), similarly as in the case of a substituent made of two condensed rings of different sizes (5 and 6-membered, compounds 24, 25 and 41, Fig. 2). Compounds with 5-membered heteroaromatic substituent have similar activity regardless of the heteroatom (oxygen (21) or nitrogen (23), Table 1). In the case of azaaromatic derivatives, replacing 5-membered ring (compound 23, Fig. 2) with 6-membered one (compound 26, Fig. 2) causes a significant decrease in the compound activity (Table 1). However, introducing bromine atom (electron-accepting substituent) in position 7 of the benzoxazole ring results in the activity increase giving the most active compound ( $\mathrm{H}-\mathrm{Box}(4 \mathrm{PyBr})-\mathrm{OMe}$ (34)) among heterocyclic derivatives of benzoxazolylalanine (Table 1). Minimal inhibitory concentration value for $\mathrm{H}-\mathrm{Box}(4 \mathrm{PyBr})-\mathrm{OMe}$ (compound 34) was almost three times lower compared to H-Box(4Py)-OMe (compound 26), whereas H-Box(2Py)-OMe (compound 27) did not show any activity in contrast to $\mathrm{H}-\mathrm{Box}(2 \mathrm{PyBr})-\mathrm{OMe}$ (compound $\mathbf{3 5}$, Table 1). It suggests that antimicrobial activity depends on the position of the nitrogen atom in the substituent. This should be also true for quinolinyl derivatives; however, due to the poor solubility of 3 compounds in the medium used MIC determination and clear analysis of the results was difficult. To estimate the influence of the nitrogen atom position 
on the activity of the compound, the amount of each quinolinyl derivative present on the paper disk during the screening tests inhibiting yeast's growth was calculated. The results are as follows: $\mathrm{H}-\mathrm{Box}(2 \mathrm{Q})-\mathrm{OMe}$ (compound 28) $-11 \mu \mathrm{g}$, H-Box(3Q)-OMe (compound 29)-12 $\mu \mathrm{g}, \mathrm{H}-\mathrm{Box}(3 \mathrm{iQ})-\mathrm{OMe}$ (compound 30)-24 $\mu \mathrm{g}, \mathrm{H}-\mathrm{Box}(6 \mathrm{Q})-\mathrm{OMe}$ (compound 31) $20 \mu \mathrm{g}, \mathrm{H}-\mathrm{Box}(4 \mathrm{Q})-\mathrm{OMe}$ (compound 32)—6 $\mu \mathrm{g}, \mathrm{H}-\mathrm{Box}(8 \mathrm{Q})-$ OMe (compound 33) $-64 \mu \mathrm{g}$. Their analysis showed that more active are compounds with nitrogen atom present in the ring directly connected to the benzoxazole moiety $(4 \mathrm{Q}$, 2Q, 3Q, 3iQ, Fig. 2).

Only 3 out of 17 tested compounds, namely H-Box[(2$\left.\mathrm{OMe}-4-\mathrm{NMe}_{2}\right) \mathrm{Ph}$ ]-OMe (compound 13), H-Box (2Q)-OMe (compound 28), H-Box(4PyBr)-OMe (compound 34), exhibited activity against pathogenic yeast $C$. albicans. Moreover, their antifungal activity (reflected in MIC values) was about two or four times lower comparing to their effect observed for P. pastoris (Table 1).

\section{Cytotoxicological studies}

To assess whether studied benzoxazolylalanine derivatives are potential anticancer agents, the cytotoxic effect of all studied compounds, except four derivatives with very low solubility, was screened using rat glioma cell line (C6). It was found that 7 compounds were not cytotoxic in the studied concentration range $\left(\mathrm{H}-\mathrm{Box}\left[2,4-(\mathrm{OH})_{2} \mathrm{Ph}\right]-\mathrm{OMe}\right.$ (15), H-Box[(4-Me)Ph]-OH (36), H-Box(BiPh)-OH (37), and H-Box (2-Bfur)-OH (41) (2-500 $\mu \mathrm{M})$, H-Box(2-Naph)$\mathrm{OH}(\mathbf{3 8}, 4-1000 \mu \mathrm{M}), \mathrm{H}-\mathrm{Box}[(4-\mathrm{COOH}) \mathrm{Ph}]-\mathrm{OMe}(\mathbf{4}$, 20-5000 $\mu \mathrm{M})$, and H-Box(2-Im)-OH (40, 40-10000 $\mu \mathrm{M})$ (Table 2). Among them are mainly compounds without C-terminal methyl ester suggesting that the state of $\alpha$-carboxyl group is important for such activity. It is also confirmed by the results obtained for the compounds 1 $(\mathrm{H}-\mathrm{Box}[(4-\mathrm{Me}) \mathrm{Ph}]-\mathrm{OMe}-$ cytotoxic) and 36 (H-Box[(4$\mathrm{Me}) \mathrm{Ph}]-\mathrm{OH}$ - not cytotoxic).

For cytotoxic compounds, the structure-activity relationship was observed (Table 2). Among phenyl derivatives of benzoxazolylalanine (compounds 1-20, Fig. 2), these with phenyl substituted only in position 4 (compounds $\mathbf{1 - 3}, \mathbf{5}$, 10-12, 16, and 20) have similar cytotoxicity, in most cases regardless of the type of the substituent (Table 2). Introducing additional substituents to the phenyl ring results in diminishing cytotoxicity, except for substitution in position 3 which seems to be the most important one (compounds 8-9 and 13-15). Such substituted compounds are more cytotoxic as in the case of $\mathrm{H}-\mathrm{Box}\left[3-\mathrm{B}(\mathrm{OH})_{2} \mathrm{Ph}\right]-\mathrm{OMe}$ (compound 17) which cytotoxic effect is five times higher than this of $\mathrm{H}-\mathrm{Box}\left[4-\mathrm{B}(\mathrm{OH})_{2} \mathrm{Ph}\right]-\mathrm{OMe}$ (compound 16, Table 2). Toxicity of derivatives with double substituted phenyl depends on both the position and the type of substituents (compounds 7, 13-15 and 19, Fig. 2, Table 2). In such cases, the most important seems to be the substitution of position 4 of the phenyl as the presence of additional group in position 2 of the phenyl (H-Box[(2-OMe-4-NMe 2$) \mathrm{Ph}]-\mathrm{OMe}(\mathbf{1 3}))$ slightly increases cytotoxicity of the compound, whereas lack of its dimethylamino group in position $4(\mathrm{H}-\mathrm{Box}[(2-\mathrm{OMe}) \mathrm{Ph}]-$ $\mathrm{OMe}(\mathbf{6})$ ) causes twofold reduction of compound's cytotoxicity (Table 2). Also, changing these substituents for hydroxyl and diethylamino groups (H-Box $\left[\left(2-\mathrm{OH}-4-\mathrm{NEt}_{2}\right) \mathrm{Ph}\right]-\mathrm{OMe}$ (14)) or two hydroxyl groups (H-Box[2,4- $\left.(\mathrm{OH})_{2} \mathrm{Ph}\right]-\mathrm{OMe}$ (15)) causes a significant decrease in cytotoxicity (Table 2).

Benzoxazolylalanine derivatives containing in position 2 small heterocyclic substituent (furan, thiophene, pyrrole) are relatively not very cytotoxic (compounds $\mathbf{2 1 - 2 3}$, Table 2). The least toxic among them is H-Box(Tio)-OMe (22); however, the exchange of thiophene for benzothiophene (compound 25) makes the compound the most toxic one in this group. In the case of derivatives with oxygen as a heteroatom in the substituent (compounds 21 and 41), an inverse relationship is observed (Table 2).

Cytotoxicity of derivatives with azaaromatic substituents depends on a size of the heterocyclic ring (compounds $\mathbf{2 3}$, 24 and 26-35). Compound with five-membered ring as a substituent (H-Box(Pyrrol)-OMe (23)) is more toxic than these with six-membered ones (H-Box(2Py)-OMe (27) and H-Box(4Py)-OMe (26)). However, introducing azaaromatic substituent larger than pyridine (quinoline - compounds 28-33) significantly increases cytotoxicity of the compound (Table 2). Cytotoxicity of both of these derivatives (pyridyl and quinolinyl) depends on the position of the nitrogen in the aromatic ring: the closer to the benzoxazole ring, the higher toxicity of the compound (Table 2). Also, introducing the bromine atom (electron-accepting substituent) in position 7 of the benzoxazole ring (compounds 34 and 35) slightly increases the cytotoxicity of the pyridyl derivatives (Table 2).

Based on the results of the screening tests described above, 19 compounds were selected for further studies performed for three normal cell lines (A9, HDF, and Hek293). Cells of A9 line are more sensitive to the presence of majority of studied compounds than these of C6 line (Table 2). The exceptions are three phenyl derivatives (H-Box[2,4,5$\left.(\mathrm{OMe})_{3} \mathrm{Ph}\right]-\mathrm{OMe}(\mathbf{8}), \mathrm{H}-\mathrm{Box}\left[3,4,5-(\mathrm{OMe})_{3} \mathrm{Ph}\right]-\mathrm{OMe}(\mathbf{9})$, $\left.\mathrm{H}-\mathrm{Box}\left[4-\mathrm{B}(\mathrm{OH})_{2} \mathrm{Ph}\right]-\mathrm{OMe}(\mathbf{1 6})\right)$ which are less toxic for A9 cell line. However, the structure-activity relationships observed for A9 cell line are similar as these for C6. For phenyl derivatives, the importance of substituent in position 3 of the phenyl as well as the presence of the dimethylamino group in position 4 is more pronounced than in the case of A9 cell line $\left(\mathrm{EC}_{50}\right.$ value for $\mathrm{H}-\mathrm{Box}\left[3-\mathrm{B}(\mathrm{OH})_{2} \mathrm{Ph}\right]-\mathrm{OMe}(\mathbf{1 7})$ is ten times lower than $\mathrm{EC}_{50}$ value for $\mathrm{H}-\mathrm{Box}\left[4-\mathrm{B}(\mathrm{OH})_{2} \mathrm{Ph}\right]-$ $\mathrm{OMe}(\mathbf{1 6})$ ). Also, more than one group of the same type in the phenyl ring causes a decrease in cytotoxicity (compounds $\mathbf{7}$ and $\mathbf{8}$, Table 2). Furthermore, compounds with 
Table 2 Cytotoxicity $\left(\mathrm{EC}_{50}\right)$ of studied compounds to selected cell lines

\begin{tabular}{|c|c|c|c|c|c|}
\hline \multicolumn{2}{|c|}{ Compound } & \multicolumn{4}{|l|}{$\mathrm{EC}_{50}[\mu \mathrm{M}]$} \\
\hline No. & Designation & $\begin{array}{l}\text { Rat glioma } \\
\text { (C6) }\end{array}$ & $\begin{array}{l}\text { Mouse fibroblasts } \\
\text { (A9) }\end{array}$ & $\begin{array}{l}\text { Human dermal fibro- } \\
\text { blasts (HDF) }\end{array}$ & $\begin{array}{l}\text { Human } \\
\text { embryonic } \\
\text { kidney } \\
\text { (Hek293) }\end{array}$ \\
\hline 1 & $\mathrm{H}-\mathrm{Box}[(4-\mathrm{Me}) \mathrm{Ph}]-\mathrm{OMe}$ & $309 \pm 7$ & nd & nd & nd \\
\hline 2 & $\mathrm{H}-\mathrm{Box}[(4-\mathrm{F}) \mathrm{Ph}]-\mathrm{OMe}$ & $372 \pm 3$ & nd & nd & nd \\
\hline 3 & $\mathrm{H}-\mathrm{Box}[(4-\mathrm{CN}) \mathrm{Ph}]-\mathrm{OMe}$ & $286 \pm 7$ & nd & nd & nd \\
\hline 4 & $\mathrm{H}-\mathrm{Box}[(4-\mathrm{COOH}) \mathrm{Ph}]-\mathrm{OMe}$ & No effect & nd & nd & nd \\
\hline 5 & $\mathrm{H}-\mathrm{Box}[(4-\mathrm{Br}) \mathrm{Ph}]-\mathrm{OMe}$ & $230 \pm 1$ & $80 \pm 5$ & $46 \pm 0.3$ & $238 \pm 15$ \\
\hline 6 & $\mathrm{H}-\mathrm{Box}[(2-\mathrm{OMe}) \mathrm{Ph}]-\mathrm{OMe}$ & $438 \pm 20$ & $334 \pm 22$ & $100 \pm 2$ & $718 \pm 92$ \\
\hline 7 & $\mathrm{H}-\mathrm{Box}\left[2,5-(\mathrm{OMe})_{2} \mathrm{Ph}\right]-\mathrm{OMe}$ & $900 \pm 21$ & $354 \pm 33$ & $60 \pm 4$ & $256 \pm 21$ \\
\hline 8 & $\mathrm{H}-\mathrm{Box}\left[2,4,5-(\mathrm{OMe})_{3} \mathrm{Ph}\right]-\mathrm{OMe}$ & $832 \pm 58$ & $1700 \pm 25$ & $238 \pm 9$ & $745 \pm 135$ \\
\hline 9 & $\mathrm{H}-\mathrm{Box}\left[3,4,5-(\mathrm{OMe})_{3} \mathrm{Ph}\right]-\mathrm{OMe}$ & $317 \pm 36$ & $1459 \pm 19$ & $81 \pm 5$ & $878 \pm 70$ \\
\hline 10 & $\mathrm{H}-\mathrm{Box}[(4-\mathrm{OAll}) \mathrm{Ph}]-\mathrm{OMe}$ & $185 \pm 4$ & nd & nd & nd \\
\hline 11 & $\mathrm{H}-\mathrm{Box}\left[\left(4-\mathrm{NMe}_{2}\right) \mathrm{Ph}\right]-\mathrm{OMe}$ & $277 \pm 6$ & nd & nd & nd \\
\hline 12 & $\mathrm{H}-\mathrm{Box}\left[\left(4-\mathrm{NPh}_{2}\right) \mathrm{Ph}\right]-\mathrm{OMe}$ & $--^{\mathrm{a}}$ & nd & nd & nd \\
\hline 13 & $\mathrm{H}-\mathrm{Box}\left[\left(2-\mathrm{OMe}-4-\mathrm{NMe}_{2}\right) \mathrm{Ph}\right]-\mathrm{OMe}$ & $239 \pm 11$ & $97 \pm 3$ & $29 \pm 1$ & $314 \pm 15$ \\
\hline 14 & $\mathrm{H}-\mathrm{Box}\left[\left(2-\mathrm{OH}-4-\mathrm{NEt}_{2}\right) \mathrm{Ph}\right]-\mathrm{OMe}$ & $337 \pm 8$ & nd & nd & nd \\
\hline 15 & $\mathrm{H}-\mathrm{Box}\left[2,4-(\mathrm{OH})_{2} \mathrm{Ph}\right]-\mathrm{OMe}$ & No effect & nd & nd & nd \\
\hline 16 & $\mathrm{H}-\mathrm{Box}\left[\left(4-\mathrm{B}(\mathrm{OH})_{2}\right) \mathrm{Ph}\right]-\mathrm{OMe}$ & $299 \pm 8$ & $627 \pm 26$ & $101 \pm 18$ & Not toxic ${ }^{\mathrm{b}}$ \\
\hline 17 & $\mathrm{H}-\mathrm{Box}\left[\left(3-\mathrm{B}(\mathrm{OH})_{2}\right) \mathrm{Ph}\right]-\mathrm{OMe}$ & $59 \pm 3$ & $62 \pm 7$ & $88 \pm 15$ & $672 \pm 58$ \\
\hline 18 & $\mathrm{H}-\mathrm{Box}[(3-\mathrm{OPh}) \mathrm{Ph}]-\mathrm{OMe}$ & No effect & nd & nd & nd \\
\hline 19 & $\mathrm{H}-\mathrm{Box}\left[3,5-\left(\mathrm{CF}_{3}\right)_{2} \mathrm{Ph}\right]-\mathrm{OMe}$ & $-{ }^{\mathrm{a}}$ & nd & nd & nd \\
\hline 20 & $\mathrm{H}-\mathrm{Box}\left(4-\mathrm{NMe}_{2} \mathrm{Cin}\right)-\mathrm{OMe}$ & $229 \pm 5$ & nd & nd & nd \\
\hline 21 & H-Box(Fur)-OMe & $450 \pm 10$ & nd & nd & nd \\
\hline 22 & H-Box(Tio)-OMe & $954 \pm 44$ & nd & nd & nd \\
\hline 23 & H-Box(Pyrrol)-OMe & $418 \pm 48$ & $278 \pm 32$ & $110 \pm 2$ & $852 \pm 80$ \\
\hline 24 & H-Box(Indol)-OMe & $-^{\mathrm{a}}$ & nd & nd & nd \\
\hline 25 & H-Box(Benzotio)-OMe & $79 \pm 7$ & $53 \pm 1$ & $6 \pm 0.4$ & $437 \pm 32$ \\
\hline 26 & H-Box(4Py)-OMe & $1866 \pm 86$ & $1174 \pm 21$ & $112 \pm 9$ & $4099 \pm 131$ \\
\hline 27 & $\mathrm{H}-\mathrm{Box}(2 \mathrm{Py})-\mathrm{OMe}$ & $983 \pm 2$ & $662 \pm 49$ & $296 \pm 9$ & $1429 \pm 104$ \\
\hline 28 & H-Box(2Q)-OMe & $131 \pm 5$ & $50 \pm 3$ & $37 \pm 0.1$ & $326 \pm 19$ \\
\hline 29 & H-Box(3Q)-OMe & $299 \pm 24$ & $51 \pm 3$ & $21 \pm 1$ & $378 \pm 18$ \\
\hline 30 & $\mathrm{H}-\mathrm{Box}(3 \mathrm{iQ})-\mathrm{OMe}$ & $147 \pm 3$ & $58 \pm 4$ & $54 \pm 3$ & $290 \pm 10$ \\
\hline 31 & H-Box(6Q)-OMe & $--^{\mathrm{a}}$ & nd & nd & nd \\
\hline 32 & H-Box(4Q)-OMe & $567 \pm 20$ & $106 \pm 10$ & $26 \pm 2$ & $583 \pm 29$ \\
\hline 33 & H-Box(8Q)-OMe & $377 \pm 22$ & $313 \pm 22$ & $394 \pm 9$ & $198 \pm 5$ \\
\hline 34 & H-Box(4PyBr)-OMe & $1760 \pm 8$ & $408 \pm 3$ & $73 \pm 12$ & $3216 \pm 171$ \\
\hline 35 & $\mathrm{H}-\mathrm{Box}(2 \mathrm{PyBr})-\mathrm{OMe}$ & $965 \pm 44$ & $234 \pm 21$ & $48 \pm 4$ & $1980 \pm 112$ \\
\hline 36 & $\mathrm{H}-\mathrm{Box}[(4-\mathrm{Me}) \mathrm{Ph}]-\mathrm{OH}$ & No effect & nd & nd & nd \\
\hline 37 & $\mathrm{H}-\mathrm{Box}(\mathrm{BiPh})-\mathrm{OH}$ & No effect & nd & nd & nd \\
\hline 38 & H-Box(2-Naph)-OH & No effect & nd & nd & nd \\
\hline 39 & $\mathrm{H}-\mathrm{Box}(9-\mathrm{Ant})-\mathrm{OH}$ & $320 \pm 15$ & nd & nd & nd \\
\hline 40 & $\mathrm{H}-\mathrm{Box}(2-\mathrm{Im})-\mathrm{OH}$ & No effect & nd & nd & nd \\
\hline 41 & H-Box(2-Benzofur)-OH & No effect & nd & nd & nd \\
\hline
\end{tabular}

$n d$ not determined

${ }^{\text {a }}$ Too low solubility in the conditions of the experiment

${ }^{\mathrm{b}}$ In the concentration range of $10-2500 \mu \mathrm{M}$ 
electron-donating substituents in the phenyl ring are less toxic than these with electron-accepting groups (Table 2). In the case of azaaromatic derivatives, the greater impact of the presence of the bromine atom in position 7 of the benzoxazole ring was observed for A9 cell line (almost 3 times lower $\mathrm{EC}_{50}$ value for pyridyl derivatives with the bromine atom, Table 2). Moreover, exchanging smaller to larger azaaromatic group (pyridine to quinoline) in position 2 of the benzoxazole ring causes significant cytotoxicity increase [compounds $\mathbf{2 6}$ and $\mathbf{3 2}$ (about 11 times), 27 and 28 (about 13 times), Table 2].

Influence of studied benzoxazolylalanine derivatives on normal cell lines was assessed to establish whether their application as antimicrobial or anticancer agents would be safe for humans. As both application to the skin and administration of the drug were taken into account, human dermal fibroblasts (HDF) and human embryonic kidney (Hek293) cell lines were selected for the study. It should be emphasized that understanding potential renal toxicity is particularly important as unmetabolized drugs are largely excreted in the urine. Among studied compounds, only one (H-Box$\left.\left[4-\mathrm{B}(\mathrm{OH})_{2} \mathrm{Ph}\right]-\mathrm{OMe}(\mathbf{1 6})\right)$ was not toxic to Hek293 cell line (Table 2). This cell line was much less sensitive to the presence of studied compounds (except H-Box(8Q)-OMe (33)) than HDF cell line (Table 2). Also, the majority of studied derivatives were less cytotoxic to Hek293 than for cancer C6 as well as for normal A9 cell lines. The opposite relationship was observed for HDF cell line (Table 2). Moreover, the majority of studied derivatives has $\mathrm{EC}_{50}$ value lower than MIC value indicating on greater cytotoxicity of these compounds than their antimicrobial potential (Tables 1 and 2).

Toxicity to HDF and Hek293 cell lines depends on the structure of the compound. Among methoxyphenyl derivatives, these with double substituted phenyl ring are the most cytotoxic ones. As in the case of A9 cell line, phenyl derivatives with electron-accepting substituents are more cytotoxic than these with electron-accepting groups (Table 2). Similarly as for cancer cell line, H-Box-[3-B $\left.(\mathrm{OH})_{2} \mathrm{Ph}\right]-\mathrm{OMe}(\mathbf{1 7})$ is more toxic than $\mathrm{H}-\mathrm{Box}-\left[4-\mathrm{B}(\mathrm{OH})_{2} \mathrm{Ph}\right]-\mathrm{OMe}(\mathbf{1 6})$ for $\mathrm{HDF}$ and Hek293 cell lines (Table 2). Azaaromatic derivatives of benzoxazolylalanine (compounds $\mathbf{2 3}, \mathbf{2 6}-\mathbf{3 0}$ and $\mathbf{3 2}-\mathbf{3 5}$ ) are less toxic than compound with benzothiophene as a substituent (compound 25, Table 2). Cytotoxicity of azaaromatic derivatives depends on the size of heterocyclic ring. Compounds with 5-membered ring (pyrrole, $\mathbf{2 3}$ ) are more toxic than these with 6-membered ring (pyridine, 26 and 27). However, increasing the size of the azaaromatic substituent (compounds 28-30, 32 and 33) results in greater cytotoxicity of such compound (quinolinyl derivatives, Table 2). Moreover, azaaromatic compounds in which substituent's nitrogen atom is in spatial proximity to the benzoxazole ring (compounds $\mathbf{2 7 - 3 0}$ and $\mathbf{3 3}$ ) are more toxic, except for toxicity of pyridyl derivatives to HDF cell line (Table 2). Introducing the bromine atom in position 7 of the benzoxazole ring (compounds 34 and 35) causes significant increase of compound's toxicity to HDF cell line. In the case of Hek293 cell line, this effect is less pronounced and observed only for $\mathrm{H}-\mathrm{Box}(4 \mathrm{PyBr})-\mathrm{OMe}(\mathbf{3 4})$. For H-Box (2PyBr)-OMe (35), the opposite effect is observed (Table 2).

\section{Conclusion}

Performed screening tests concerning a large group of 3-(2-benzoxazol-5-yl)alanine derivatives (41 compounds) enabled to characterize biological activity of each compound and determine the influence of substituent in position 2 of the benzoxazole ring on it.

It was observed that studied compounds have small antibacterial potential in contrast to antifungal one. Moreover, it has been shown that the activity of the compound depends on its structure. The widest spectrum of activity has $\mathrm{H}-\mathrm{Box}\left[\left(2-\mathrm{OMe}-4-\mathrm{NMe}_{2}\right) \mathrm{Ph}\right]-\mathrm{OMe}$ (compound 13) and H-Box (2Q)-OMe (compound $\mathbf{2 8}$ ) which are active against $B$. subtilis, P. pastoris, and C. albicans. Lower minimal inhibitory concentration values make the first compound more promising as a potential antimicrobial agent. The majority of active benzoxazolylalanine derivatives are selective. Only antifungal properties are characteristic for 12 compounds of which the most important is $\mathrm{H}-\mathrm{Box}(4 \mathrm{PyBr})-\mathrm{OMe}$ (compound 34) which is also active against pathogenic C. albicans (the lowest MIC value). One compound (H-Box[2,4,5$\left.\left.(\mathrm{OMe})_{3} \mathrm{Ph}\right]-\mathrm{OMe}(\mathbf{8})\right)$ has only antibacterial properties, but its high MIC value excludes its potential use as an antibiotic.

Most of studied compounds are toxic to both cancer and normal cells. For each cell line, the structure-activity relationship was observed. Also, it was found that fibroblasts are more sensitive to the presence of benzoxazolylalanine derivatives than the other studied cell types. Moreover, almost all studied compounds are the most toxic to the human dermal fibroblasts (HDF) what exclude application of their potential pharmaceutical preparation to the skin. In the case of Hek293 cell line, almost all compounds (except compounds $\mathbf{7 , 8}$ and $\mathbf{3 3}$ ) are less toxic for this cells than for cancer cells. Among them is $\mathrm{H}-\mathrm{Box}\left[3-\mathrm{B}(\mathrm{OH})_{2} \mathrm{Ph}\right]-\mathrm{OMe}$ (compound 17) which toxicity to cancer cells is tenfold higher than to Hek293 cells and could be a candidate for anticancer agent. Similar difference between toxicity to cancer and normal cells is observed for a few more compounds. Among them, the most important is $\mathrm{H}-\mathrm{Box}(4 \mathrm{PyBr})-\mathrm{OMe}$ (compound 34) for which MIC value for pathogenic C. albicans is lower than its cytotoxic concentrations (except for HDF cell line). Toxicity of all the other antifungal compounds to normal cells (expressed as $\mathrm{EC}_{50}$ value) is higher than their antimicrobial potency (expressed as MIC values) which makes them rather useless as potential chemotherapeutic agents. 
The obtained results indicate that substituent in position 2 of the benzoxazole ring has a great influence on the antimicrobial and anticancer activity of 3-(2-benzoxazol-5-yl) alanine derivatives. Also, the state of the $\alpha$-carboxyl group (blocked or free) may be important. The structure-activity relationship established basing on studies on such a large group of compounds enabled to select candidates for further modifications. Performing additional optimization of another positions will allow to improve biological activity of these compounds and obtain a lead structure with potential for therapeutic use.

Acknowledgements The authors would like to warmly thank Prof. Andrzej C. Składanowski and his co-workers from the Laboratory of Molecular Enzymology, Intercollegiate Faculty of Biotechnology UG\&MUG for the donation of the cell lines. The authors also thank Prof. Wojciech Kamysz from the Faculty of Pharmacy, Medical University of Gdańsk for the donation of $C$. albicans strain.

Author contributions KG and WW: Conceptualization; KG, EM, and MO: Methodology; investigation and result analysis: KG (Synthesis, microbiological studies), EM (Cytotoxicological studies), MO (Microbiological studies)]; KG: Writing — original draft preparation; KG, EM, MO, and WW: Writing-review and editing; KG: Funding acquisition; MO, WW: Supervision.

Funding This work was financially supported by the Polish Ministry of Science and Higher Education under grants BW 8000-5-0264-5, BW 8000-5-0287-6 and BW 8000-5-0049-7.

\section{Declarations}

Conflict of interest The authors declare that they have no conflict of interest.

Ethical approval This article does not contain any studies with human participants or animals performed by any of the authors.

Open Access This article is licensed under a Creative Commons Attribution 4.0 International License, which permits use, sharing, adaptation, distribution and reproduction in any medium or format, as long as you give appropriate credit to the original author(s) and the source, provide a link to the Creative Commons licence, and indicate if changes were made. The images or other third party material in this article are included in the article's Creative Commons licence, unless indicated otherwise in a credit line to the material. If material is not included in the article's Creative Commons licence and your intended use is not permitted by statutory regulation or exceeds the permitted use, you will need to obtain permission directly from the copyright holder. To view a copy of this licence, visit http://creativecommons.org/licenses/by/4.0/.

\section{References}

Arpaci ÖT, Ören İ, Altanlar N (2002a) Synthesis and antimicrobial activity of some novel 2-(p-substituted-phenyl)-5-substitutedcarbonylaminobenzoxazoles. Il Farmaco 57:175-181

Arpaci ÖT, Şener EA, Yalçın İ, Altanlar N (2002b) Synthesis and microbiological activity of some novel
$\mathrm{N}$-[2-(p-substitutedphenyl)-5-benzoxazolyl]-cyclohexyl carboxamide, -cyclohexyl acetamide and -cyclohexyl propionamide derivatives. Il Farmaco 57:771-775

Bernard AM, Cabiddu MG, De Montis S, Mura R, Pompei R (2014) Synthesis of new compounds with promising antiviral properties against group A and B Human Rhinoviruses. Bioorg Med Chem 22:4061-4066

Chu Y-W, Li J-J, Wang L, Yu R (2011) Antifungal antibiotic CA1189 produced by a Mangrove endophyte Streptomyces sp. A1626. Chin J Antibiot 36:14-17

Chung HJ, Park KR, Lee HJ, Lee J, Kim J-H, Kim Y-C, Han S-Y (2015) Effects of KRC-108 on the Aurora A activity and growth of colorectal cancer cells. Biochem Biophys Res Comm 461:605-611

Daletos G, de Voogd NJ, Müller WEG, Wray V, Lin WH, Feger D, Kubbutat M, Aly AH, Proksch P (2014) Cytotoxic and protein kinase inhibiting nakijiquinones and nakijiquinols from the sponge Dactylospongia metachromia. J Nat Prod 77:218-226

De Carvalho LIS, Alvarenga DJ, do Carmo LCF, de Oliveira LG, Silva NCh, Dias ALT, Coelho LFL, de Souza TB, Dias DF, Carvalho DT (2017) Antifungal activity of new eugenol-benzoxazole hybrids against Candida spp. J Chem. https://doi.org/10.1155/ 2017/5207439

Demmer ChS, Bunch L (2015) Benzoxazoles and oxazolopyridines in medicinal chemistry studies. Eur J Med Chem 97:778-785

Desai S, Desai V, Shingade S (2020) In vitro anti-cancer assay and apoptotic cell pathway of newly synthesized benzoxazole- $N$-heterocyclic hybrids as potent tyrosine kinase inhibitors. Bioorg Chem 94:103382. https://doi.org/10.1016/j.bioorg.2019.103382

Dunwell DW, Evans D, Hicks TA (1975a) 2-Aryl-5-benzoxazolealkanoic acid derivatives with notable antiinflammatory activity. J Med Chem 18:53-58

Dunwell DW, Evans D, Hicks TA (1975b) Synthesis and antiinflammatory activity of some 2-heteroaryl- $\alpha$-methyl-5-benzoxazoleacetic acids. J Med Chem 18:1158-1159

Ertan-Bolelli T, Yildiz İ, Ozgen-Ozgacar S (2016) Synthesis, molecular docking and antimicrobial evaluation of novel benzoxazole derivatives. Med Chem Res 25:553-567

Giordano A, Forte G, Terracciano S, Russo A, Sala M, Scala MC, Johansson C, Oppermann U, Riccio R, Bruno I, Di Micco S (2019) Identification of the 2-benzoxazol-2-yl-phenol scaffold as new hit for JMJD3 inhibition. ACS Med Chem Lett 10:601-605

Gutti G, Kakarla R, Kumar D, Beohar M, Ganeshpurkar A, Kumar A, Krishnamurthy S, Singh SK (2019) Discovery of novel series of 2-substituted benzo[d]oxazol-5-amine derivatives as multi-target directed ligands for the treatment of Alzheimer's disease. Eur J Med Chem 182:111613. https://doi.org/10.1016/j.ejmech.2019. 111613

Guzow K, Szabelski M, Malicka J, Wiczk W (2001) Synthesis of a new, highly fluorescent amino acid derivative: N-Boc-3-[2- $(1 \mathrm{H}-$ indol-3-yl)-benzoxazole-5-yl]-alanine methyl ester. Helv Chim Acta 84:1086-1092

Guzow K, Szabelski M, Malicka J, Karolczak J, Wiczk W (2002) Synthesis and photophysical properties of 3-[2-(pyridyl)benzoxazol5-yl]-L-alanine derivatives. Tetrahedron 58:2201-2209

Guzow K, Mazurkiewicz K, Szabelski M, Ganzynkowicz R, Karolczak J, Wiczk W (2003) Influence of an aromatic substituent in position 2 on photophysical properties of benzoxazol-5-yl-alanine derivatives. Chem Phys 295:119-130

Guzow K, Milewska M, Wróblewski D, Giełdoń A, Wiczk W (2004) 3-[2-(8-quinolinyl)benzoxazol-5-yl]alanine derivative-a specific fluorophore for transition and rare-earth metal ions detection. Tetrahedron 60:11889-11894

Guzow K, Milewska M, Wiczk W (2005a) Solvatochromism of 3-[2-(4-diphenylaminophenyl)benzoxazol-5-yl]alanine methyl ester. A new fluorescence probe. Spectrochim Acta A 61:1133-1140 
Guzow K, Zielińska J, Mazurkiewicz K, Karolczak J, Wiczk W (2005b) Influence of substituents in the phenyl ring on photophysical properties of 3-[2-(phenyl)benzoxazol-5-yl]alanine derivatives. J Photochem Photobiol A: Chem 175:57-68

Guzow K, Szmigiel D, Wróblewski D, Milewska M, Karolczak J, Wiczk W (2007) New fluorescent probes based on 3-(2-benzoxazol-5-yl)alanine skeleton-synthesis and photophysical properties. J Photochem Photobiol A: Chem 187:87-96

Guzow K, Jażdżewska D, Wiczk W (2012) 3-[2-(Boronophenyl)benzoxazol-5-yl]alanine derivatives as fluorescent monosaccharide sensors. Tetrahedron 68:9240-9248

Han S-Y, Lee ChO, Ahn S-H, Lee M-O, Kang S-Y, Cha H-J, Cho SY, Ha JD, Ryu JW, Jung H, Kim HR, Koh JS, Lee J (2012) Evaluation of a multi-kinase inhibitor KRC-108 as an anti-tumor agent in vitro and in vivo. Invest New Drugs 30:518-523

Hohmann C, Schneider K, Bruntner Ch, Irran E, Nicholson G, Bull AT, Jones AL, Brown R, Stach JEM, Goodfellow M, Beil W, Krämer M, Imhoff JF, Süssmuth RD, Fiedler H-P (2009) Caboxamycin, a new antibiotic of the benzoxazole family produced by the deep-sea strain Streptomyces sp. NTK 937. J Antibiot 62:99-104

Huang L, Zhang W, Zhang X, Yin L, Chen B, Song J (2015) Synthesis and pharmacological evaluation of piperidine (piperazine)substituted benzoxazole derivatives as multi-target antipsychotics. Bioorg Med Chem Lett 25:5299-5305

Hyeon JW, Noh R, Choi J, Lee SM, Lee YS, An SSA, No KT, Lee J (2020) BMD42-2910, a novel benzoxazole derivative, shows a potent anti-prion activity and prolongs the mean survival in an animal model of prion disease. Exp Neurobiol 29:93-105

Ibrahim M-K, El-Adl K, Zayed MF, Mahdy HA (2015) Design, synthesis, docking, and biological evaluation of some novel 5-chloro2 -substituted sulfanylbenzoxazole derivatives as anticonvulsant agents. Med Chem Res 24:99-114

Jauhari PK, Bhavani A, Varalvar S, Singhal K, Raj P (2008) Synthesis of some novel 2-substituted benzoxazoles as anticancer, antifungal, and antimicrobial agents. Med Chem Res 17:412-424

Jonckers THM, Rouan M-C, Haché G, Schepens W, Hallenberger S, Baumeister J, Sasaki JC (2012) Benzoxazole and benzothiazole amides as novel pharmacokinetic enhancers of HIV protease inhibitors. Bioorg Med Chem Lett 22:4998-5002

Kakkar S, Narasimhan B (2019) A comprehensive review on biological activities of oxazole derivatives. BMC Chem 13:16. https://doi. org/10.1186/s13065-019-0531-9

Kakkar S, Tahlan S, Lim SM, Ramasamy K, Mani V, Shah SAA, Narasimhan B (2018) Benzoxazole derivatives: design, synthesis and biological evaluation. Chem Cent J 12:92. https://doi.org/10.1186/ s13065-018-0459-5

Kaur A, Pathak DP, Sharma V, Wakode S (2018) Synthesis, molecular docking, and pharmacological evaluation of $N$-(2-(3,5-dimethoxyphenyl)benzoxazole-5-yl)benzamide derivatives as selective COX-2 inhibitors and anti-inflammatory agents. Arch Pharm Chem Life Sci 351:e1800008. https://doi.org/10.1002/ardp.20180 0008

Kumar D, Jacob MR, Reynolds MB, Kerwin SM (2002) Synthesis and evaluation of anticancer benzoxazoles and benzimidazoles related to UK-1. Bioorg Med Chem 10:3997-4004

Kuroyanagi J-I, Kanai K, Sugimoto Y, Horiuchi T, Achiwa I, Takeshita H, Kawakami K (2010) 1,3-Benzoxazole-4-carbonitrile as a novel antifungal scaffold of $\beta-1,6$-glucan synthesis inhibitors. Biorg Med Chem 18:7593-7606

Kuroyanagi J-I, Kanai K, Horiuchi T, Takeshita H, Kobayashi S, Achiwa I, Yoshida K, Nakamura K, Kawakami K (2011) Structure-activity relationships of 1,3-benzoxazole-4-carbonitriles as novel antifungal agents with potent in vivo efficacy. Chem Pharm Bull 59:341-352

Lewis DFV, Ioannides C, Parke DV (1990) A retrospective study of the molecular toxicology of benoxaprofen. Toxicology 65:33-47
Li Ch, Cui J-F, Chen M-B, Liu C-Y, Liu F, Zhang O-D, Zou J, Lu P-H (2015) The preclinical evaluation of the dual mTORC1/2 inhibitor INK-128 as a potential anti-colorectal cancer agent. Cancer Biol Ther 16(1):34-42. https://doi.org/10.4161/15384047.2014.972274

Omar A-MME, AboulWafa OM, El-Shoukrofy MS, Amr ME (2020) Benzoxazole derivatives as new generation of anti-breast cancer agents. Bioorg Chem 96:103593. https://doi.org/10.1016/j.bioorg. 2020.103593

Ongarora DSB, Strydom N, Wicht K, Njogore M, Wiesner L, Egan TJ, Wittlin S, Jurva U, Masimirembva CM, Chibale K (2015) Antimalarial benzoheterocyclic 4-aminoquinolines: structure-activity relationship, in vivo evaluation, mechanistic and bioactivation studies. Bioorg Med Chem 23:5419-5432

Pal S, Manjunath B, Ghorai S, Sasmal S (2018) Benzoxazole alkaloids: occurrence, chemistry, and biology. In: Knölker H-J (ed) The alkaloids: chemistry and biology, vol 79. Academic Press, Cambridge, San Diego, Oxford, London, pp 71-137

Prudhomme M, Dauphin G, Guyot J, Jeminet G (1984) Semisynthesis of A23187 (calcimycin) analogues. II Introduction of a methyl group on the benzoxazole ring. J Antibiot 37:627-634

Prudhomme M, Dauphin G, Jeminet G (1986a) Semi-synthesis of A23187 (calcimycin) analogs. III. Modification of benzoxazole ring substituents, ionophorous properties in an organic phase. $\mathbf{J}$ Antibiot 39:922-933

Prudhomme M, Guyot J, Jeminet G (1986b) Semi-synthesis of A23187 (calcimycin) analogs. IV. Cation carrier properties in mitochondria of analogs with modified benzoxazole rings. Antimicrobial activity. J Antibiot 39:934-937

Pytela O, Klimešová V (2011) Effect of substitution on the antimycobacterial activity of 2-(substituted benzyl)sulfanyl benzimidazoles, benzoxazoles, and benzothiazoles - a quantitative structureactivity relationship study. Chem Pharm Bull 59:179-184

Rana DN, Chhabria MT, Shah NK, Brahmkshatriya PS (2014a) Pharmacophore combination as a useful strategy to discover new antitubercular agents. Med Chem Res 23:370-381

Rana DN, Chhabria MT, Shah NK, Brahmkshatriya PS (2014b) Discovery of new antitubercular agents by combining pyrazoline and benzoxazole pharmacophores: design, synthesis and insights into the binding interactions. Med Chem Res 23:2218-2228

Ranke J, Molter K, Stock F, Bottin-Weber U, Poczobutt J, Hoffman J, Ondruschka B, Filser J, Jastorff B (2004) Biological effect of imidazolium ionic liquids with varying chain lengths in acute Vibro fisheri and WST-1 cell viability assays. Ecotoxicol Environ Saf 58:396-404

Reddy NB, Burra VR, Ravindranath LK, Sreenivasulu R, Kumar VN (2016) Synthesis and biological evaluation of benzoxazole fused combretastatin derivatives as anticancer agents. Monatsh Chem 147:593-598

Reynolds MB, DeLuca MR, Kerwin SM (1999) The novel bis(benzoxazole) cytotoxic natural product UK-1 is a magnesium ion-dependent DNA binding agent and inhibitor of human topoisomerase II. Bioorg Chem 27:326-337

Rida SM, Ashour FA, El-Hawash SAM, ElSemary MM, Badr MH, Shalaby MA (2005) Synthesis of some novel benzoxazole derivatives as anticancer, anti-HIV and antimicrobial agents. Eur J Med Chem 40:949-959

Sachweh MCC, Stafford WC, Drummond CJ, McCarthy AR, Higgins M, Campbell J, Brodin B, Arnér ESJ, Laín S (2015) Redox effect and cytotoxic profiles of MJ25 and auranofin towards malignant melanoma cells. Oncotarget 6:16488-16506

Sarma HK, Sharma BK, Tiwari SC (2003) A novel calcimycin antibiotic from Gram-positive actinomycete Frankia microsymbiont. Curr Sci 85:1401-1403

Sato S, Kajiura M, Noguchi M, Takehana K, Kobayashi T, Tsuji T (2001) AJI9561, a new cytotoxic benzoxazole derivative produced by Streptomyces sp. J Antibiot 54:102-104 
Sattar R, Mukhtar R, Atif M, Hasnain M, Irfan A (2020) Synthetic transformations and biological screening of benzoxazole derivatives: a review. J Heterocyclic Chem 57:2079-2107

Şener EA, Arpaci ÖT, Yalçın İ, Altanlar N (2000) Synthesis and microbiological activity of some novel 5-benzamido- and 5-phenylacetamido- substituted 2-phenylbenzoxazole derivatives. Il Farmaco 55:397-405

Seth K, Garg SK, Kumar R, Purohit P, Meena VS, Goyal R, Banerjee UC, Chakraborti AK (2014) 2-(2-Arylphenyl)benzoxazole as a novel anti-inflammatory scaffold: synthesis and biological evaluation. ACS Med Chem Lett 5:512-516

Sever B, Akalın ÇG, Altıntop MD (2021) A new series of benzoxazolebased SIRT1 modulators for targeted therapy of non-small-cell lung cancer. Arch Pharm (Weinheim) 354:e2000235. https://doi. org/10.1002/ardp.202000235

Šlachtová V, Brulíková L (2018) Benzoxazole derivatives as promising antitubercular agents. Chemistry Select 3:4653-4662

Slotkin EK, Patwardhan PP, Vasudeva SD, de Stanchina E, Tap WD, Schwartz GK (2016) MLN0128, an ATP-competitive mTOR kinase inhibitor with potent in vitro and in vivo antitumor activity, as potential therapy for bone and soft-tissue sarcoma. Mol Cancer Ther 14:395-406

Sommer PS, Almeida C, Schneider K, Beil W, Süssmuth RD, Fiedler HP (2008) Nataxazole, a new benzoxazole derivative with antitumor activity produced by Streptomyces sp. Tü 6176. J Antibiot 61:683-686

Song M-X, Huang Y, Wang S, Wang Z-T, Deng X-Q (2019) Design, synthesis, and evaluation of anticonvulsant activities of benzoxazole derivatives containing the 1,2,4-triazolone moiety. Arch Pharm Chem Life Sci 352:1800313. https://doi.org/10.1002/ardp. 201800313

Sun M, Zhang X, Hao H, Li W, Lu Ch (2015) Nocarbenzoxazoles A-G, benzoxazoles produced by halophilic Nocardiopsis lucentensis DSM 44048. J Nat Prod 78:2123-2127

Takahashi Y, Kubota T, Shibazaki A, Gonoi T, Fromont J, Kobayashi J (2011) Nakijinamines C-E, new heteroaromatic alkaloids from the sponge Suberites species. Org Lett 13:3016-3019

Tekiner-Gulbas B, Temiz-Arpacı Ö, Yıldız İ, Altanlar N (2007) Synthesis and in vitro antimicrobial activity of new 2-[p-substitutedbenzyl]-5-[substituted-carbonylamino]benzoxazoles. Eur J Med Chem 42:1293-1299
Temiz Ö, Ören İ, Şener E, Yalçın İ, Uçartürk N (1998) Synthesis and microbiological activity of some novel 5- or 6-methyl2-(2,4-disubstituted phenyl)benzoxazole derivatives. Il Farmaco 53:337-341

Temiz Ö, Yıldız İ, Özkan S, Kaynak F, Aki-Şener E, Yalçın İ (2008) Synthesis and biological activity of some new benzoxazoles. Eur J Med Chem 43:1423-1431

Ueki M, Taniguchi M (1997) UK-1, a novel cytotoxic metabolite from Streptomyces sp. 517-02. 3. Antibacterial action of demethyl UK-1. J Antibiot 50:788-790

Ueki M, Ueno K, Miyadoh S, Abe K, Shibata K, Taniguchi M, Oi S (1993) UK-1, a novel cytotoxic metabolite from Streptomyces sp. 517-02. I. Taxonomy, fermentation, isolation, physico-chemical and biological properties. J Antibiot 46:1089-1094

Ueki M, Kusumoto A, Hanafi M, Shibata K, Tanaka T, Taniguchi M (1997) UK-3A, a novel antifungal antibiotic from Streptomyces sp. 517-02: fermentation, isolation, structural elucidation and biological properties. J Antibiot 50:551-555

Wiegand I, Hilpert K, Hancock REW (2008) Agar and broth dilution methods to determine the minimal inhibitory concentration (MIC) of antimicrobial substances. Nat Protoc 3:163-175

Zhang H-Z, Zhao Z-L, Zhou C-H (2018) Recent advance in oxazolebased medical chemistry. Eur J Med Chem 144:444-492

Zhong W, Tang X, Liu Y, Zhou Ch, Liu P, Li E, Zhong P, Lv H, Zou Q, Wang M (2020) Benzoxazole derivatives K313 induces cell cycle arrest, apoptosis and autophagy blockage and suppresses mTOR/ p70S6K pathway in Nalm-6 and Daudi cells. Molecules 25:971. https://doi.org/10.3390/molecules25040971

Zi M, Liu F, Wu D, Li K, Zhang D, Zhu Ch, Zhang Z, Li L, Zhang C, Xie M, Lin J, Zhang J, Jin Y (2019) Discovery of 6-arylurea-2-arylbenzoxazole and 6-arylurea-2-arylbenzimidazole derivatives as angiogenesis inhibitors: design, synthesis and in vitro biological evaluation. ChemMedChem 14:1291-1302

Publisher's Note Springer Nature remains neutral with regard to jurisdictional claims in published maps and institutional affiliations. 